INTERNATIONAL JOURNAL OF RESEARCHES IN BIOSCIENCES, AGRICULTURE \& TECHNOLOGY (C) VISHWASHANTI MULTIPURPOSE SOCIETY (Global Peace Multipurpose Society) R. No. MH-659/13(N) www.vmsindia.org

\title{
STUDIES ON THE SEASONAL VARIATIONS OF SOME PHYSICO-CHEMICAL CHARACTERISTICS OF SAKHARWAHI RESERVOIR OF CHANDRAPUR DISTRICT (M.S.), INDIA.
}

\author{
1Wahane M.S., ${ }^{1}$ Gedam Y. B. and 2 Pandao S.P. \\ ${ }^{1}$ Janata College Chandrapur (M.S.) India \\ ${ }^{2}$ Arts, Commerce and Science College Tukum, Chandrapur (M.S) India \\ Email: sppandao@gmail.com
}

\begin{abstract}
Ecosystem is made up of biodiversity which includes both biotic as well as abiotic components Aquatic Ecosystem is influenced by physico-chemical parameters of water body. The aquatic ecosystem depends on the physico-chemical parameters of water body. Out of the total amount of global water, only $2.4 \%$ is distributed on the main land of which only a small portion can be used as fresh water. Many physico-chemical and biological factors adversely affect the growth and development of fish and other living organism of ecosystem. Hence regular monitoring of these factors is essential to know the status of water for drinking and other uses. In the present study some physico-chemical parameters of Sakharwahi Reservoir is examined from Feb 2015 to Jan 2016. Water samples were collected every month and examined for Temperature of water, Dissolved Oxygen, free $\mathrm{CO}_{2}, \mathrm{pH}$, Total alkalinity, Transparency etc.
\end{abstract}

Keywords: Seasonal variations, Physico-chemical Characteristics, Sakharwahi

\section{Introduction:}

Study of physico-chemical and biological characteristics of different water bodies gives the basic information about biodiversity in that particular area. Reservoir is natural or artificial pond or lake used for the storage and regulation of water. The limnology of reservoirs has many similarities to that of lakes of equivalent size. Many limnological studies were held from different regions of Maharashtra. Telkhade (2007), Khinchi et.al., (2009), Dhere and Gaikwad, (2006); Ingole, S. B. Pawale, Wavde (2009), Goel et.al. (1980). However no such work was carried out on Sakharwahi reservoir in Chandrapur district of Maharashtra, so the present work was undertaken to study the seasonal variations in some physico-chemical characteristics of Sakharwahi reservoir.

Sakharwahi reservoir is the oldest reservoir of Sakharwahi village of Chandrapur district. It is spread in $5.13 \mathrm{Sq}$. $\mathrm{Km}$. of land. It has catchment area 9.13 Sq.km. It has water holding capacity 310.00 tcm. It is a rich source of water supply for agriculture, pisciculture and other domestic uses. For the present study 3 sites of reservoir were selected as Site 1 , Site 2, and Site 3. The air is generally dry from Feb to May. The climate of reservoir area is semiarid and experiences hot summer.

\section{Material and Methods:}

From the 3 sites i.e. S1, S2 and S3 of Sakharwahi reservoir water samples were collected in each month from Feb. 2015 to Jan. 2016. The selected samples were examined for Water Temperature, Transparency, $\mathrm{pH}$, Free $\mathrm{CO}_{2}$, DO and Total alkalinity. On the sites using different methods of analysis the various physicochemical parameters are examined as given in the methodology for water analysis (Trivedi and Goel, 1984), APHA (1980) and Kodarkar et.al. (1998) Temperature was measured by goal mercury filled thermometer, $\mathrm{pH}$ measured by using Hanna made $\mathrm{pH}$ meter at the water samples collection sites. The chemical parameters of water samples such as $\mathrm{DO}$, free $\mathrm{CO}_{2}$, total alkalinity were examined by standard methods described by APHA (1980), Trivedi et.al., (1998). Transparency was determined by Secchi disc method at the site.

Table-1.1 Physico-chemical profile of Sakharwahi reservoir (From Feb. 2015 to Jan. 2016)

\begin{tabular}{|c|l|l|}
\hline Sr. No. & \multicolumn{1}{|c|}{ Parameters } & \multicolumn{1}{c|}{ Range } \\
\hline 1 & Temperature & $23.3-37.4$ \\
\hline 2 & Transperancy & $27.0-84.5$ \\
\hline 3 & $\mathrm{pH}$ & $07.0-08.2$ \\
\hline 4 & Free Carbondioxide & $02.16-05.10$ \\
\hline 5 & Dissolved Oxygen & $3.02-9.90$ \\
\hline 6 & Total Alkalinity & $47.4-141.8$ \\
\hline
\end{tabular}


Table -1.2 Average values of seasonal variation in Physico-chemical parameters at different sites of Sakharwahi Reservoir

\begin{tabular}{|c|c|c|c|c|c|c|c|}
\hline Sr. No. & Parameters & Season & $\mathbf{s 1}$ & $\mathbf{s 2}$ & S3 & Min. & Max. \\
\hline \multirow[t]{3}{*}{ 1) } & Temperature & Summer & 33.6 & 33.8 & 33.6 & 33.6 & 33.8 \\
\hline & & Rainy & 31.6 & 31.6 & 31.5 & 31.5 & 31.6 \\
\hline & & Winter & 25.6 & 25.8 & 25.6 & 25.6 & 25.8 \\
\hline \multirow[t]{3}{*}{ 2) } & Transperancy & Summer & 73.9 & 71.8 & 75.3 & 71.8 & 75.3 \\
\hline & & Rainy & 34.4 & 35 & 35.5 & 34.4 & 35.5 \\
\hline & & Winter & 50.6 & 48.6 & 51.7 & 48.6 & 51.7 \\
\hline \multirow[t]{3}{*}{ 3) } & $\mathrm{pH}$ & Summer & 8.08 & 7.91 & 7.85 & 7.85 & 8.08 \\
\hline & & Rainy & 7.62 & 7.94 & 7.58 & 7.58 & 7.94 \\
\hline & & Winter & 7.05 & 7.24 & 7.14 & 7.05 & 7.24 \\
\hline \multirow[t]{3}{*}{ 4) } & Free $\mathrm{CO}_{2}$ & Summer & 4.44 & 4.95 & 4.59 & 4.44 & 4.95 \\
\hline & & Rainy & 3.79 & 4.07 & 3.95 & 3.79 & 4.07 \\
\hline & & Winter & 2.62 & 3.34 & 2.94 & 2.62 & 3.34 \\
\hline \multirow[t]{3}{*}{ 5) } & Dissolved Oxygen & Summer & 7.6 & 6.82 & 7.51 & 6.82 & 7.6 \\
\hline & & Rainy & 5.06 & 4 & 4.75 & 4 & 5.06 \\
\hline & & Winter & 8.72 & 7.49 & 8.67 & 7.49 & 8.72 \\
\hline \multirow[t]{3}{*}{ 6) } & Total Alkalinity & Summer & 62.18 & 62.63 & 62.35 & 62.18 & 62.63 \\
\hline & & Rainy & 50.81 & 51.01 & 50.85 & 50.81 & 51.01 \\
\hline & & Winter & 114.1 & 114.6 & 114.6 & 114.1 & 114.7 \\
\hline
\end{tabular}

\section{Result and discussion:}

The result of analysis is summarized in the table 1.1, 1.2. During the study period water temperature of Sakharwahi reservoir had showed fluctuations ranging from $23.3^{\circ} \mathrm{C}$ to $37.70^{\circ} \mathrm{C}$. In May (summer) season maximum temperature was recorded $37.40^{\circ} \mathrm{C}$ and minimum temperature $23.3^{\circ} \mathrm{C}$ was observed in Jan (Winter) season from 3 sites of lake. (Table 1.2)

The water temperature closely paralleled the air temperature in tropical region the annual changes in temperature closely reflect seasonal pattern. Chandran and Ramamorthy (1984) pointed out that changes in water temp. was mainly due to atmospheric temperature. Aquatic ecosystem in greately influenced by temperature of reservoir. It affects chemical solutes, dissolved gases and phytoplankton of the lake. Reservoir with temperature $>22^{\circ} \mathrm{C}$ is high productive reservoir (Jhingran and Sugunan, 1990). The average temperature of Sakharwahi reservoir recorded $30.33^{\circ} \mathrm{C}$. This exhibits that the reservoir is highly productive. Same results were observed by Rao (1955), Saha and Pandit (1986).

Water transparency is important characteristic of water varied due to the combined effect of colour and turbidity. Transparency of surface water decided the development and distribution of plants and animal life in fresh water. In general the values of transparency was shown variation between $27.00 \mathrm{~cm}$ to $84.50 \mathrm{~cm}$. The minimum transparency of $27.00 \mathrm{~cm}$ was recorded at site 1 in August and maximum transparency $84.50 \mathrm{~cm}$ was recorded in site 3 in March. Sharma et.al. (2008) similar results was recorded in Ningland stream and Shittu et.al. (2008) in Nigeria.

$\mathrm{pH}$ affects the organic and inorganic solutes and $\mathrm{CO}_{2}$ in waterbody in present 
investigation $\mathrm{pH}$ was shown variation between 7.01 to 8.21 . The minimum $\mathrm{pH}$ of 7.01 was recorded at site 1 in Dec. and maximum 8.21 was recorded at Site 1 in month of June. The high $\mathrm{pH}$ recorded during winter and summer can be attributed to higher productivity of water as evidenced by high growth rate of algal population which utilized $\mathrm{CO}_{2}$ for photosynthesis.

Dissolved oxygen is the important parameter which decides the quality of water. In water body, organic, inorganic materials are present and thus there is requirement of oxygen.

In present study DO ranged between 3.02 to $9.90 \mathrm{mg} / 1$. The result indicated that no specific, annual, seasonal or spatial pattern could be recognized during the study period. When DO was low it indicated that the water was very much eutrophied and hence $\mathrm{O}_{2}$ demands were very acute both chemically and biologically. Duration of sunlight and associated temperature increases DO in water body (Marimuthu et.al. 1990) during monsoon all sites recorded high DO due to heavy rainfall. Rainwater bring on highly DO (Khalaf and Mac Donald 1975, Qasim and Gopinathan (1989). Low DO value may be due to the decomposition of organic matter which imposes of organic matter which requires high amount of DO. Low DO may indicate sewage pollution Venkateswaralu (1986)

Alkalinity is the capacity of water to neutralize strong acids. It is developed due to addition of salts like carbonates, phosphates, bicarbonates, nitrates. In present study maximum alkalinity were recorded during winter season at site 3 , $141.80 \mathrm{mg} / \mathrm{l}$ and minimum value of alkalinity were recorded during summer (June) all sites. The lowest value of 47.45 $\mathrm{mg} / 1$ was recorded at site 1 during the month of September 2015. Morris et.al. (1980) recorded the same observation in South Erie River of Tasmania. Thus in the present study high alkalinity was observed in winter and minimum in summer and monsoon. The same result were observed by Kulshrestha et.al. (1992) and Deshmuk (2001), Sakhare (2005). The free $\mathrm{CO}_{2}$ contents varied from 2.16 to $5.10 \mathrm{mg} / 1$.
Maximum free $\mathrm{CO}_{2}$ content was observed in rainy season and minimum during winter and summer.

\section{Conclusion:}

The conclusion of the investigation is the, physico-chemical characteristics of Sakharwahi reservoir, it shows variation due to seasons and environmental conditions. It can be well summarized that, temperature was maximum in summer and minimum was recorded in winter. $\mathrm{pH}$ was generally alkaline in all three sites. Dissolved oxygen was less during summer. Alkalinity was more in winter while $\mathrm{CO}_{2}$ was maximum in summer and monsoon season. This study suggested that water quality of Sakharwahi lake is suited for irrigation, pisciculture and for other domestic purposes.

\section{Acknowledgement:}

The authors are thankful to President of Chanda Shikshan Prasarak Mandal Sau. Dr. Prtibhatai A. Jiwtode, secretary of Chanda Shikshan Prasarak Mandal Dr. Ashokbhau Jiwtode, Principal of Janata Mahavidyalaya, Chandrapur. Dr. M. Subhas to provide all necessary facilities for present research study.

\section{References :}

A.P.H.A. 1980. Standard Methods for the Examination of Water and Wastewater.

New York, 15th ed. Pp. 1134.

Dhembare, J.(2011) European Journal of Experimental Biology, 1(2), 68-76.

Dhere, R.M. and Gaikwad, J.M. (2006) Physico-chemical characteristics of Karpara Reservoir, Dist. Parbhani, Maharashtra, J.Aqua Biol., 21(2) : 86-88.

Goel et.al. (1980) : Impact of Sewage on fresh water ecosystem - II, Physico-chemical characteristics of water and their seasonal variations. Indian J. Ecology and Environmental Sci. Vol. (8) : pp 83-96.

Ingole, S.B., Pawale, R.G. and Wavde, P.N. (2009) Water quality studies on Majalgaon dam, Beed district, Maharashtra, J. Aqua Biol., 24 (1) : 71-76.

Jhingran Arun, G. and Sugunan, V.v. (1990) General guidelines and planning criteria for small reservoir fisheries management. In Reservoir Fisheries in India (Jhingran A.G. and V. K. Unnithan Eds.) pp. 1-8. Asian Fisheries Society, Indian Branch, Mangalore, India.

Khabade, S.K., Mule, M.B. and Sathe, S.S. (2002) Studies on physico-chemical 
parameters of lodhe water reservoir from Tasgaon Tahsil (Maharashtra) : Indian $\mathrm{J}$. Environ. And Ecoplan, 6(2) : 301-304.

Khanna, D.R. and Bhutiani, R. (2003) Ecological status of Sitapur pond at Hardwar (Uttaranchal) Indian J. Environ. And Ecoplan, 72(1) : 175-178.

Khinchi, P.J. (2009) Seasonal variations of flora and fauna in Junona lake of Chandrapur district (Maharashtra) India, with respect of Physico-chemical characteristics, Ph.D. Thesis submitted to R.T.M., Nagpur University, Nagpur.

Kodarkar, M.S., Diwan, A.D., Murugan, N. Kulkarni, K.M. and Anuradha Ramesh (1998) Methodology for water analysis (Physico-chemical, Biological and Microbiological) Indian Asso. Of Aqua. Biologists, Hyderabad. Pp. 102.

Kulshrestha, S.K., George, M.P., Saxena, Rashmi, Johri, Malini and Shrivastava, Manish (1992) Seasonal variations in the limnochemical characteristics of Mansarovar reservoir of Bhopal. In Aquatic Ecology (S.R. Mishra and D. N. Saksena Eds.), pp 275-292, Ashish Publishing House, New Delhi, India.

Masood, A. and Krishnamurthy, R. (1990) : Hydrobiological studies of Wohar reservoir, Aurangabad (Maharashtra State) India. Indian J. Environ. Biol, 11(3) : 335-343.

Pande, K.S. and Sharma, S.D. (1998) Studies of toxic pollutants in Ramganga river at Moradabad, India Envtal Geo., 1(2) : 93-96.

Pawar, S.K. and Phule, J.S. (2005) Studies on physico-chemical parameters in Pethwadaj dam, Nanded district in Maharashtra, India. Indian J. Aqua. Biol, 20(2) : 123-128.

Rao, C.B. (1955) On the distribution of algae in a group of six small ponds II. Algae periodicity. J Ecol. 43 : 291-308.

Rasool, S., Msatyakala, H.K. and Suryanarayanmurthy U. (2003) Studies on the physico-chemical parameters of Rankala lake, Kolhapur, (2003) IJEP 2399, pp. 961963.
Raut, K.S., Shinde, S.E., Pathan, T.S., and Sonawane, D.L. (2011) Seasonal variations in physico-chemical characteristics of Ravivar Peth lake at Ambejogai Dist. Beed, Marathawada Region, India. Journal of Research Biology, 4 : 258262.

Saha, L.C. and Pandit, B. (1986) Comparative limnology of Bhagalpur ponds. Comp. Phyiol. Ecol. 1 (14) : 213-216.

Saikh, N. and Yeragi, S.G. (2004) Some physico-chemical aspects of Tansa River of Thane district, Maharashtra, J. Aqua Biol., 19(1) : 99-102.

Sarkar, R. and Krishnanmoorthi, K.P. (1977) : Biological method for monitoring water pollution level : studies at Nagpur. Indian J. Environ. Health, 19(2) : 132-139.

Sharma Dushyant and Jain Renu (2000) Physico Chemical Analysis of Gopalpura Tank of Guna District (M.P.) Ecol. Env. \& Cons 6(4) : 441-445.

Singh, C.S., Sharma, A.P. and Deorari, B.P. (1993) Limnological Studies for Bioenergetic Transformation in a Tarai Reservoir, Nanak Sagar (U.P.) In Advances in Limnology (H.R. Singh Ed.) pp. 29-44. Narendra Publishing House, Delhi.

Sirsat, D. B. Ambore, N.E. and Pulle, J.S. (2004) Study of phytoplankton of fresh water pond at Dharmapuri in Beed District (Maharashtra). J. Aqua Biol., 19(2) : 7-10.

Telkhede, P.M., Dahegaonkar, N.R., Zade, S.B. and Lonkar, A.N. (2008) Quantitative analysis of Phytoplanktons and Zooplanktons of Masala Lake, Masala, Dist. Chandrapur, Maharashtra. Envrn. Cosr. Jou., 9(1\&2) : 37-40.

Trivedy, R. K. and Goel, P.K. (1984) Chemical and Biological methods for water pollution studies. Environmental publications, Karad. pp 244.

Verma, J. and Mohanty, R.C. (1995) Phytoplankton and its correlation with certain physico-chemical parameters of Danmukundpur pond, Res. 14 : 233-242. 